$$
\text { No. } 4204 \text { May 27, } 1950
$$

to displace the trypaflavine. This seems to confirm our hypothesis that the competition between quaternary ammonium salts and trypaflavine takes place for positions on the cell surface commanding the entrance of trypaflavine in the cell. The same kind of experiments with spermine and inorganic cations instead of the quatornary ammonium salts suggests that here, too, the activity of these cations in preventing the inhibition of respiration by trypaflavine is due to competition for negatively charged groups of the cell surface. Our present experiments have also confirmed the high affinity of trypaflavine for nucleic acids we have described in earlier papers ${ }^{2-5}$.

Our observations on the inhibition of respiration by baker's yeast and the prevention of this inhibition by all kinds of cations not themselves inhibitors, together with the laws governing this prevention (importance of valency of inorganic cations $^{2}$, surface-activity for quaternary ammonium salts), suggest that: (1) trypaflavine is adsorbed at the protoplasmic membrane by acidic groupings prior to its entrance in the yeast cell; (2) this adsorption can be prevented by other cations which are bound by the seme acidic groupings by means of Coulomb forces, and that competition for these groupings takes place (cation exchange); (3) trypa. flavine exerts its inhibiting activity in the interior of the yeast cell.

Full details of these experiments will be published elsewhere.

We thank the firm of Labaz (Belgium) for a gift of quaternary ammonium compounds.

$$
\begin{aligned}
& \text { L. MAssart } \\
& \text { J. VAN DER StOCK }
\end{aligned}
$$

Biochemical Laboratory, University of Ghent. Jan. 16.

1 Albert, A., Rubbo, S. D., Goldacre, R. J., Davey, M. E., and Stone, J. D., Brit. J. Exp. Path., 36, 160 (ig45).

2 Massart, L., Peeters, G., and Wuyts-Robiette, J., Arch. int. Pharm. Thér., 75,162 (1947).

${ }^{8}$ Massart, I., Van den Daelen, P., and De Nayer, H., Arch. int. Pharm. Thér., 77,383 (1948).

- Massart, L., Arch. int. Pharm. Therr., 77, 88 (1948).

${ }^{3}$ Massart, I., Nature, 162, 778 (1948); Arch. int. Pharm. Thér., 79,

- Silverman, M., and Evans, E. A., J. Biol. Chem., 150, 267 (1943).

'Silverman, M., Arch. Biochem., 19, 193 (1948).

${ }^{8}$ Van der Stock, J. (unpublished results).

\section{Insecticidal Action of DDT}

SINCE the discovery of the outstanding insecticidal activity of $1: 1:$ 1-trichloro-2 : 2-di-(4-chlorophenyl) ethane (DDT), many analogues have been synthesized, and several investigators ${ }^{1,2}$ have reached the conclusion that the most toxic are also the most similar to DDT in shape and size. If the toxicity is due to its structural resemblance to some essential insect metabolite or to cholesterol ${ }^{3}$, then compounds isosteric with DDT ought to act similarly, and replacement of the three $\beta$-chlorine atoms by spatially similar atoms or groups of atoms should not destroy activity. Suitable groups were thought to be $-\mathrm{CH}_{3}$ (radius $1.7 \mathrm{~A}$.) and - $\mathrm{OH}$ (radius $2.0 \mathrm{~A}$.), which conform reasonably well with $\mathrm{Cl}$ (radius $1 \cdot 7 \mathrm{~A}$.) an agreement which has been shown to be well within the limits required for isosteric activity in serological reactions.

Accordingly, compounds I, II, III and IV were prepared and tested against Calandra granaria L. ${ }^{5}$. All showed little or no activity as contact insecticides.
(I)
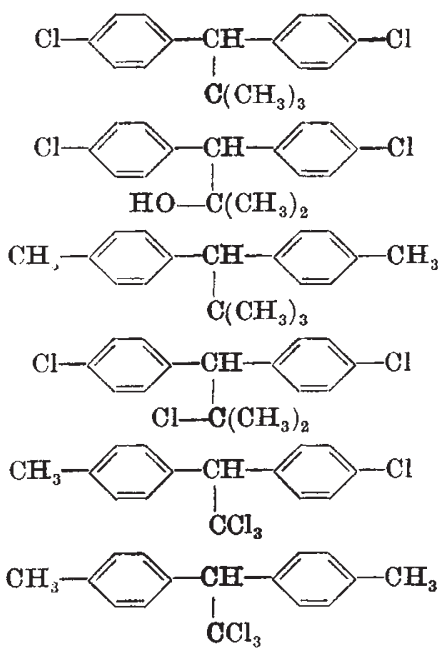

This is significant in view of the fact that $(\mathrm{V})$ and (VI) are also isosteric with DDT, but are appreciably insecticidal ${ }^{6, ?}$. Whether this is due to their ability to lose hydrochloric acid ${ }^{8}$ or to some intrinsic property of the $-\mathrm{CCl}_{\mathbf{3}}$ group $^{9}$ is still obscure, though the former possibility seems less probable in view of the inactivity of (IV), which becomes dehydrochlorinated readily to a mixture of ethylenes.

Further work is in progress and will be fully reported elsewhere.

\section{E. JoHN SKERRETT}

A. Stringer

University of Bristol Agricultural and

$$
\text { D. WOODCOCK }
$$

Horticultural Research Station, Long Ashton, Bristol.

$$
\text { Jan. } 7 .
$$

1 Busvine, J. R., J. Soc. Chem. Indust., 65, 356 (1946).

${ }^{2}$ Prill, E. A., Synerholm, M. E., and Hartzell, A., Contrib. Boyce Thompson Inst., 14 (6), 341 (1946).

${ }^{3}$ Läuger, P., et. al., "Mechanism of Intoxication of DDT Insecticides in Insects and Warm-blooded Animals" (Geigy Co., New York). 4 Pauling, L., and Pressman, D., J. Amer. Chem. Soc., 67, 1003 (1945). ${ }^{5}$ Stringer, A., Ann. App. Biol., 36, 213 (1949).

Martin, H., and Wain, R. I., Ann. Rep. Res. Sta. Long Ashton 1944,126 .

${ }^{7}$ Bennett, S. H., Martin, H. Stringer, A., and Woodcock, D., Ann. Rep. Res. Sta. Long Ashton 1948, 138 .

${ }^{8}$ Martin, H., and Wain, R. L., Nature, 154, 512 (1944).

Erlenmeyer, H., Bitterlei, P., and Sorkin, E., Helv. Chim. Acta, 31, 466 (1948).

\section{Substances with Fungicidal Activity in the Bark of Deciduous Trees}

Some years ago it was found that the bark of the balsam peplar Populus candicans contains substances with fungistatic activity, and that these substances can be isolated from the bark by extraction with boiling water ${ }^{1}$.

Further investigation has made clear that the extract can be concentrated by evaporation of water at boiling point, without loss of activity. When added in sufficient concentration to a nutrient agar, the growth of Stereum purpureum on it was completely inhibited, and the fungus died. The action is therefore not only fungistatic, but also fungicidal.

Other species of the genus Populus have been tested ; first of all the balsam poplar $P$. trichocarpa, which gave extracts with fungicidal activity as strong as $P$. candicans. The bark of $P$. monilifera, $P$. robusta, 